\title{
Multi Variant Process Plans
}

\author{
MONKA, P.; MONKOVA, K. \& ZAJAC, J.
}

Abstract: The article deals with the use of computer aided process planning in relation to the characteristics of the European market. It introduces the method of "multi-variable process plans" dedicated to engineering activities taking place prior to the production process.

The aforementioned method was founded by the authors at the Technical University in Kosice and it enables a favourable provision of technological and production documentation by built-in instruments for adopting decisions in shorter time. This form of production preparation allows a greater flexibility of manufacturing units when searching for the means of effective production processes with the required economic results.

Key words: computer aided production, process plan design, process planning, production information system
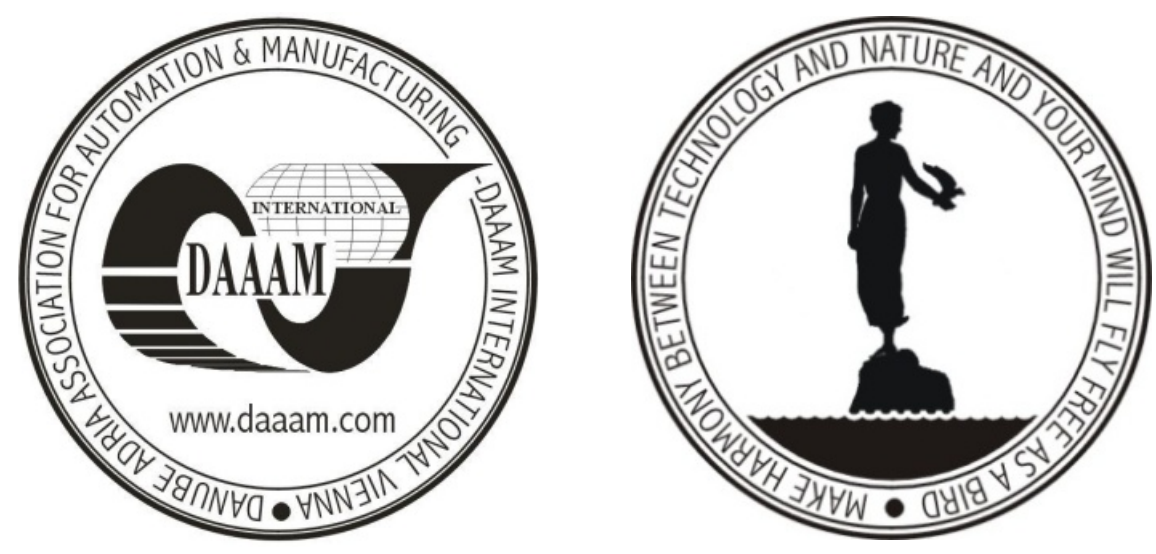

Author's data: Dr. Doc. Eng. PhD. Monka, P[eter]; Dr. Doc. Eng. PhD. Monkova, K[atarina]; Prof. Eng. CSc. Zajac J[ozef], Technical University of Kosice, Faculty of Manufacturing Technologies, Sturova 31, 080 01, Presov, Slovakia, peter.monka@tuke.sk, katarina.monkova@tuke.sk, jozef.zajac@tuke.sk

This Publication has to be referred as: Monka, P[eter]; Monkova, K[atarina] \& Zajac J[ozef], (2009). Multi Variant Process Plans, Chapter 86 in DAAAM International Scientific Book 2009, pp. 889-896, B. Katalinic (Ed.), Published by DAAAM International, ISBN 978-3-901509-69-8, ISSN 1726-9687, Vienna, Austria DOI: $10.2507 /$ daaam.scibook.2009.86 